\title{
Introduction to Gabrielle Ferrieres' Jean Cavailles (1950).
}

\author{
Camille Akmut
}

January 15,2020

\begin{abstract}
Contextualization, including a timeline of Cavailles' post-War commemoration and a re-evaluation of Ferrieres' wider work.
\end{abstract}




\section{Gabrielle Ferrieres, ethnographer of human loss and pain}

The first edition of Georges Canguilhem's Life and death held :

"The most moving and best ["sure"] biography of Jean Cavailles is (no doubt) that of his sister."

Due to the own celebrity of the author, Canguilhem's volume of speeches remains better known - published under various titles/formats, of which in turn "Life and Death" appears to be the most durable ${ }^{1}$.

Gabrielle Ferrieres's biography however offers insights which cannot be obtained otherwise : on the young Cavailles.

The chapters "Childhood" and "Adolescence" are of particular interest in that regard, followed by those on his college years ("Ecole normale") and the time he spent in Germany before World War II ("Rockefeller stipend").

It is this part that we offer here as translation. - Let us also try to give a timeline of Cavailles' reception and commemoration/celebration after the War :

- 1944 : Cavailles executed, dumped inside an anonymous grave (number 5)

- 1945 : remains identified as those of Cavailles ${ }^{2}$

- 1945 : Raymond Aron's "Jean Cavailles" article

- 1946 : exhumed, transferred and re-buried in the Sorbonne Chapel

- 1946 : later sociologist Georges Friedman's Leibniz and Spinoza study appears with a dedication to Cavailles and Bloch ${ }^{3}$

- 1947 : On Logic and the Theory of Science

- 1950 : Gabrielle Ferrieres writes biography of Cavailles (published with PUF, major French academic publishing house)

- 1967 : Cavailles auditorium created at the Strasbourg University, inaugural speech by Canguilhem (first of three to appear in Life and Death)

- 1969, Sept. : Army of Shadows is released, features multiple works by Cavailles

- 1969, Oct. : Canguilhem proclaims his admiration of Cavailles on public radio France Culture : "a hero" (second speech)

- 1974 : Cavailles Room inaugurated at the Sorbonne (third speech)

- 1976 : Canguilhem, "Life and death"

By then, Cavailles' legacy was mostly assured, saved : immortalized with the phrase "philosopher-mathematician, carrier of bombs", coming from a respected contemporary philosopher (The Normal and Pathological, The concept of reflex in the 17th-18th c.), and put onto the big screen by author-filmmaker Melville

\footnotetext{
${ }^{1}$ In the sum "Complete works of science", these speeches, and a fourth one, appear under the title In Memoriam. (The fourth one : a later France Culture interview from 1989.)

2 "In December of 1945, the identification of the "unknown n. 5", executed by the Germans, seems now certain". Fourth speech by Canguilhem.

${ }^{3}$ Ibid (Works on science).

${ }^{4}$ See the relevant section in Complete works on science (CNRS). We are unclear as to why the current edition holds that the Pierre Laleure edition was first published in 1984.
} 
(Breathless, Leon Morin, Le Samourai $)^{5}$, himself a former Resistance member, as character "Luc Jardie". Jardie... Yet another nickname/cypher. Cavailles, the enigma. ${ }^{6}$

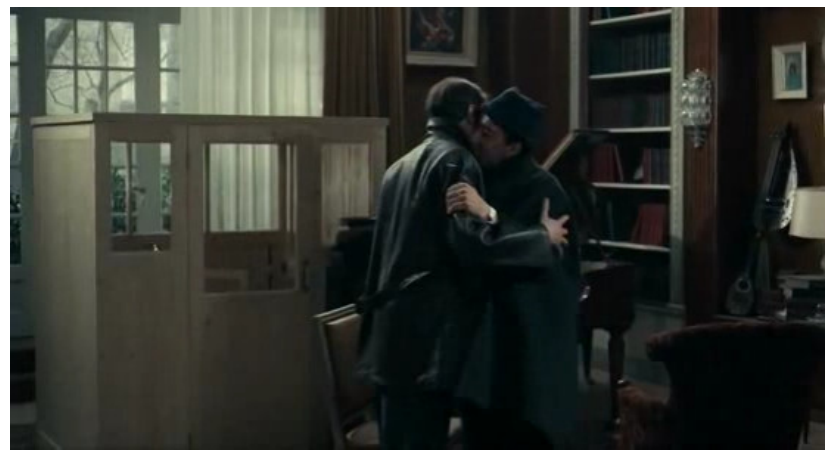

Figure 1: the two Jardie, Army of Shadows

This was succeeded by regular commemorations in each following decade (coinciding with 1944, or February) : the publication of a new edition of "Life and death" in 1984, etc..

The latest edition of the biography features a preface by philosopher Jacques Bouveresse, the backcover a quote by Canguilhem ${ }^{7}$ :

Ordinarily, writing a Moral means a philosopher is preparing to die in their bed [sleep]. Cavailles, on the other hand, at the very same moment he was doing everything he could, when one is preparing to die while fighting, wrote a Logic. Thus he gave us his "Moral", without having to write it.

$$
* * *
$$

Ferrieres had chosen the subtitle Philosopher and fighter ["combattant"] in 1950. "Philosopher in times of war" [dans la guerre] newer editions' cover hold.

Gabrielle Ferrieres was herself the author of multiple books, all adorned with tragic titles; turned ethnographer of pain, she became a recipient and analyst of modern, anonymous despair. The voice on the other end of distress lines.

In this one, Gabrielle, the sister, remembered a dearly loved just lost brother.

\footnotetext{
${ }^{5}$ Note that, not unlike many great works of art (whose unifying characteristic might be to not seek or create consensus), Army was initially poorly received by some critics. See Melville's own testimony in Melville on Melville (with Nogueira).

${ }^{6}$ It is worth noting that two characters wear the name Jardie in Army of Shadows : one is a flamboyant pilot, man of action; the other a philosopher. Split into respectively Jean-Francois and Luc. Cavailles was both, we can argue. (Luc calls him "petit Jean", opening embrace..)

${ }^{7} \mathrm{~A}$ combat intellectual too (an intellectual sharpshooter), Canguilhem's judgements were often devastating against types of philosophies (or sciences) he regarded as less rigorous (if not felonious, e.g. psychology). Moralism here, existentialism there : cf. the lines on Sartre.
} 
Gabrielle Ferriere bibliography (selected)

1950. Jean Cavailles.

1973. Sauras-tu me reconnaitre. [Will you be able to recognize me] (non-fiction)

1979. Chemin de nulle part. [Roads of/to nowhere] (novel)

1996. Voix sans visages. [Faces without voices] (non-fiction) 
GABRIELLE FERRIERES - JEAN CAVAILLES. PHILOSOPHER AND COMBATANT. (1950) 